\section{Japan names institutes in search for global excellence}

Japan has selected its five World Premier International Research Centers (WPIs), a group of institutes that will share US\$70 million per year for up to ten years (see Nature 447, 362-363; 2007).

A central goal of the WPI initiative is to create world-leading research organizations by attracting foreign scientists and collaborating with foreign institutions. For instance, the National Institute for Materials Science in Tsukuba, named as a WPI, aims to make materials for sustainable development through a new technology called nanoarchitectonics. It already has collaborators lined up in the United States, South Korea, China and the Czech Republic.

But there were few surprises among the chosen five, or in the fact that Japan's most prestigious national universities - Tokyo, Kyoto, Osaka and Tohoku - each has one designated WPI.

\section{California gets Australia's top stem-cell scientist}

California's \$3-billion stem-cell research programme has finally acquired a new leader.

Australian Alan Trounson was named last week as the president of the San Franciscobased California Institute for Regenerative Medicine (CIRM). He currently works at Monash University in Victoria, Australia, and has done pioneering work on in vitro fertilization and stem cells.

Trounson's appointment has taken some by surprise. When the board of the CIRM appointed Richard Murphy as interim president in August this year, it was suggested he could stay until March 2008.

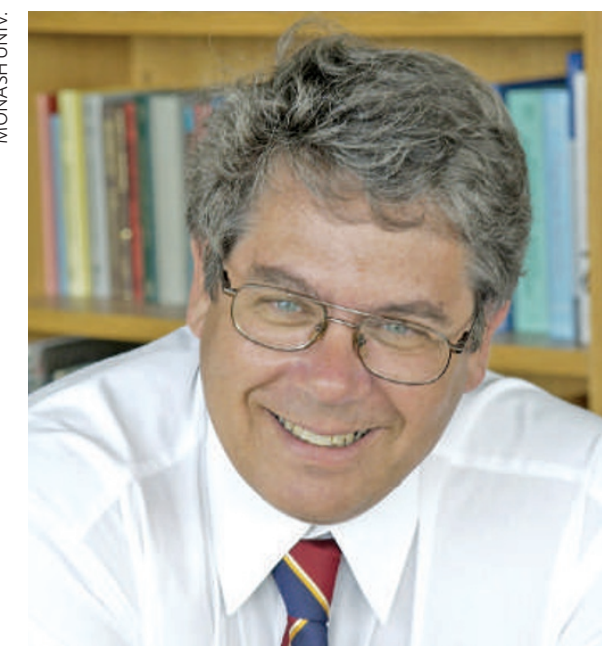

Alan Trounson will be the next president of the California Institute for Regenerative Medicine.

\title{
NASA photos are used in court case over divine bridge
}

A high-profile Indian court case has invoked NASA imagery to help clarify whether a submerged chain of sandbanks is a bridge of legend or not.

The religious text Ramayana recounts how the Hindu god Ram, with an army of monkeys, built a stone bridge from India to Sri Lanka to rescue his kidnapped wife Sita from a demon king. Last week, India's Supreme Court heard arguments over whether the 48-kilometrelong underwater ridge visible in satellite photos (right, as seen by the Terra satellite) is in fact the Hindu relic.

The suit, brought by the opposition Bharatiya Janata Party, aims to stop a US $\$ 600$-million project to convert the narrow strait between

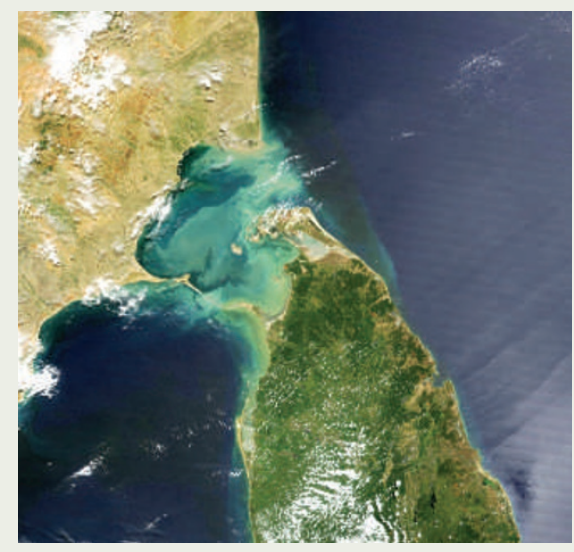

India and Sri Lanka into a shipping lane. Meanwhile, the Congress Party in power has argued that the project is vital for the country's economy - and also cited NASA's own clarification that satellite photos give no proof that the so-called Ram's bridge was man-made.

On 14 September, the court postponed its verdict until January 2008. The government has agreed to re-examine the project to see whether the shipping channel can be created without boring through the controversial ridge.

The institute had been without a permanent president since Zach Hall resigned in April.

The first $\$ 250$ million in bonds to fund the research programme is due to be issued by California state shortly.

\section{Judge backs US states' bid to curb exhaust emissions}

A federal judge in Vermont has ruled in favour of California's efforts to restrict the levels of greenhouse gases spewing from automobile exhaust pipes.

Under the US Clean Air Act, California has special provision to make its airpollution rules stronger than federal rules. At least 11 states have joined California since 2002 in its quest to regulate greenhouse gases. Car makers sued, saying that the states were usurping the role of the federal government to set standards for fuel economy - the most obvious way to limit greenhouse-gas emissions. The case came to trial first in Vermont.

But environmentalists aren't ready for their low-carbon victory lap yet. The US Environmental Protection Agency has still not given California official permission to go ahead with the new regulations, despite a 2 April Supreme Court decision ordering the agency to consider the request.

\section{Climate-change science programme 'lacks impact'}

Federal research into climate change has a long way to go in informing US policy decisions, says a new independent analysis.

The United States spends $\$ 1.7$ billion each year on climate-change research, spread among different agencies under the rubric of the US Climate Change Science Program. One of its main tasks is to produce 21 federally approved reports on the state of climate science (see Nature 436, 890; 2005), but because of bureaucratic hold-ups, only two of these long-delayed reports have appeared.

A panel convened by the US National Research Council has now evaluated the programme and found it lacking in several areas, including the evaluation of mitigation of and adaptation to climate change and in helping policy-makers incorporate climate science into their decisions.

The programme has done well in some areas, the panel added - such as documenting temperature increases and other climate-related changes on a global scale.

\section{Fly to the Moon and land $\$ 20$ million, urges Google}

The 'Google Lunar X Prize' aims to extend private space travel well out of Earth's orbit.

The US\$20-million prize, sponsored by Google and run by the X Prize Foundation in Santa Monica, California, will go to the first privately funded group that sends a rover to the lunar surface and accomplishes tasks that include roving for at least 500 metres and beaming images and videos back to Earth. In 2004, the foundation awarded \$10 million to the team that developed the first private piloted craft that went into suborbital space.

The total prize money is available until the end of 2012, then the purse drops to \$15 million until the end of 2014 - after which the competition will be cancelled. 